\title{
Volume 2 Nomor 1, September 2020
}

\section{EKSISTENSI MAHKAMAH KEHORMATAN DEWAN PASCA BERLAKUNYA UNDANG-UNDANG NOMOR 2 TAHUN 2018 TENTANG MAJELIS PERMUSYAWARATAN RAKYAT, DEWAN PERWAKILAN RAKYAT, DEWAN PERWAKILAN DAERAH, DAN DEWAN PERWAKILAN RAKYAT DAERAH}

\author{
Wahyu \\ Sekolah Tinggi Agama Islam Al-Azhar Gowa, wahyu@darulaman.sch.id
}

\begin{abstract}
Abstrak
Mahkamah Kehormatan Dewan (MKD) merupakan salah satu alat kelengkapan dewan yang memiliki tujuan dalam penegakan kode etik. Tujuan dari penulisan artikel ini adalah untuk mengetahui dan menganalisis sejauhmana eksistensi MKD berdasarkan Undang-Undang Nomor 17 Tahun 2014 dan Undang-Undang Nomor 2 tahun 2018 tentang MPR, DPR, DPD, dan DPRD. Adapun metode penelitian yang digunakan adalah metode penelitian normatif. Hasil penelitian menunjukkan bahwa dalam Undang-Undang Nomor 17 Tahun 2014, kemudian perubahan kedua yakni Undang-Undang Nomor 2 Tahun 2018 tentang MPR, DPR, DPD, dan DPRD menjelaskan bahwa MKD adalah alat kelengkapan DPR bersifat tetap yang keangotaannya berasal dari internal DPR dan dalam pelanggaran kode etik tertentu memungkinkan adanya unsur dari luar MKD. Hal itu untuk menepis anggapan bahwa MKD tidak independen dalam menangani anggota dewan yang diduga melanggar kode etik.

Kata kunci : Mahkamah Kehormatan Dewan (MKD); Alat Kelengkapan Dewan
\end{abstract}

\begin{abstract}
The Court of Council Honorific is one of complementary council organ which has a purpose in establishing a code of conduct. This study aims to know and analyze the existence of Court of Council Honorific. The study uses a normative method. The result of the study shows based on Act 17 in 2014, and than Act 2 in 2018 explain that the Court of Council Honorific has constancy which membership belongs to the inside parliament. In the violation of a certain code of ethics, it allow for elements from outside of the Court of Council Honorific. That is to dismiss that notion the Court of Council Honorific is not independent to handle the council members who suspected of breaking the code of conduct.
\end{abstract}

\section{Pendahuluan}

Pada hakikatnya, sesuai dengan prinsip kedaulatan rakyat, maka rakyatlah yang dianggap sebagai pemegang kekuasaan tertinggi dalam kegiatan bernegara. Dalam perspektif kedaulatan rakyat, semua kekuasaan dalam konteks kenegaraan berasal dan bersumber dari rakyat. Jikapun fungsi-fungsi kekuasaan negara itu dibedakan dalam 
tiga cabang utama yaitu legislatif, eksekutif, dan yudikatif maka ketiga-tiganya dianggap sama-sama berasal dari rakyat yang berdaulat. Karena pentingnya prinsip kedaulatan rakyat itu, maka sumber norma yang terkandung dalam segala bentuk peraturan perundang-undangan yang mengikat untuk umum haruslah berasal dari atau atas persetujuan dari rakyat sendiri sebagai pemilik kedaulatan atau kekuasaan tertinggi dalam negara Republik Indonesia ${ }^{1}$.

Pada peringatan Hari Parlemen Indonesia yang jatuh setiap 16 Oktober, setiap legislator di semua tingkatan harus menjadikan momentum untuk mengevaluasi diri dan kelembagaan terkait pentingnya peran parlemen sebagai wakil rakyat yang harus senantiasa memperjuangkan kepentingan rakyat. Anggota DPR RI Nevi Zuairina mengingatkan parlemen di semua tingkatan baik tingkat pusat dan daerah untuk menjadikan hari parlemen tahun ini, menjadi tonggak sejarah baru perbaikan lembaga legislatif di semua level yang selama ini banyak dihiasi oleh beberapa suara sumbang akibat kasus-kasus moral. Besar harapan agar Anggota DPR terpilih benar-benar melaksanakan kewajibannya sebagai wakil rakyat. ${ }^{2}$

Dalam melaksanakan kewenangannya disebutkan dalam Undang-Undang Nomor 2 tahun 2018 tentang perubahan kedua atas undang-undang nomor 17 tahun 2014 tentang Majelis Permusyawaratan Rakyat, Dewan Perwakilan Rakyat, Dewan Perwakilan Daerah, Dan Dewan Perwakilan Rakyat Daerah Pasal 83 bahwa dalam menjalankan tugas dan wewenangnya, dilengkapi dengan beberapa alat kelengkapan yang terdiri dari Pimpinan, Badan Musyawarah, Komisi, Badan Legislasi, Badan Anggaran, Badan Akuntabilitas Keuangan Negara, Badan Kerja Sama Antar-Parlemen, Mahkamah Kehormatan Dewan, Badan Urusan Rumah Tangga, Panitia Khusus; dan Alat Kelengkapan Lain Yang Diperlukan Dan Dibentuk Oleh Rapat Paripurna.

Mahkamah kehormatan dewan yang disingkat MKD dibentuk oleh DPR yang merupakan alat kelengkapan yang bersifat tetap, dengan tujuan untuk menindak tegas anggota dewan yang melanggar kode etik dewan. Hal ini diawali terkait banyaknya isu dari masyarakat maupun diberbagai media tentang kasus-kasus yang menjerat para anggota dewan. Eksistensi MKD ini bermula Pada tahun 2004 dimana pada awal pembentukannya bernama Dewan Kehormatan (DK) lalu menjadi Badan Kehormatan

\footnotetext{
1 Jimly Assiddiqie, (2010), Perihal Undang-Undang, PT Raja Grafindo Persada, Jakarta, hal. 259

${ }^{2}$ https://mediaindonesia.com/read/detail/265856-hari-parlemen-indonesia-jadi-pengingat-amanat-kedaulatanrakyat
} 
(BK) kemudian berganti nama menjadi Mahkamah Kehormatan Dewan (MKD) pada tahun 2014 atau sejak disahkannya Undang-Undang Nomor 17 Tahun 2014. Pembentukan Dewan Kehormatan menjawab tanggapan atas sorotan publik terhadap kinerja buruk sebagaian anggota Dewan Perwakilan Rakyat pada saat itu.

MKD termasuk alat kelengkapan Dewan Perwakilan Rakyat Republik Indonesia yang bertujuan menjaga serta menegakkan kehormatan dan keluhuran martabat Dewan Perwakilan Rakyat (DPR), sebagai lembaga perwakilan rakyat yang sangat diharapkan oleh rakyat untuk memperjuangkan nasib mereka dengan kebijakankebijakan terutama dalam tataran legislasi.

Pengawasan terhadap lembaga negara terkhusus lembaga legislatif/parlemen sangat penting disamping pengawasan eksternal, dan juga pengawasan internal untuk menghindari perbuatan yang dapat menurunkan martabat anggota dewan, sebagai lembaga yang mewakili rakyat tentunya rakyat sangat menaruh harapan besar terhadap lembaga legislatif karena dari lembaga inilah kebijakan-kebijakan strategis dirumuskan yang tentunya sangat berdampak pada nasip rakyat itu sendiri.

Kelembagaan parlemen modern memungkinkan dibentuknya lembaga penegak etik bagi anggota parlemen. Hal ini didasarkan pada pemikiran bahwa parlemen yang berevolusi menjadi lebih baik memungkinkan untuk dapat diawasi terhadap setiap perilaku dalam menjalankan tugas-tugas institusionalnya. Pengawasan terhadap perilaku anggota parlemen dapat berasal dari luar kelembagaan parlemen maupun dari internal parlemen. Pengawasan eksternal bisa dilakukan oleh konstituen secara langsung maupun oleh partai politik. Pengawasan dari dalam dapat dilakukan oleh sebuah lembaga yang dibentuk oleh parlemen itu sendiri yang dalam konsep konteks parlemen indonesia disebut dengan Badan Kehormatan (BK) atau Mahkamah Kehormatan Dewan (MKD) 3 .

Sehingga begitu besar peran lembaga parlemen dalam sistem pemerintahan modern, untuk itu upaya untuk tetap mengawasi dan menjaga harkat dan martabat dari lembaga parlemen semakin dibutuhkan, karena harkat dan martabat parlemen sesungguhnya tergantung pada tingkah laku anggota parlemen itu sendiri. Jika kelakuan anggota parlemen baik dan mulia maka dengan sendirinya parlemen menjadi

\footnotetext{
${ }^{3}$ Sri Karyati, (2005), Rekonstruksi Kelembagaan Penegakan Etika Parlemen, Jurnal Etika dan Pemilu, v1n1hal. 60
} 
lebih baik dan dihargai oleh rakyat, oleh karena itu perlu lembaga yang bersifat tetap yang harus mengawasi dan menjaga keluhuran perilaku anggota parlemen ${ }^{4}$.

\section{Metode}

Penulisan artikel ini menggunakan metode penelitian hukum dengan pendekatan peraturan perundang-undangan. Pendekatan peraturan perundang-undangan adalah suatu pendekatan yang mengacu pada hukum dan peraturan perundang-undangan yang berlaku yaitu Undang Undang Nomor 22 Tahun 2003 tentang Susunan dan Kedudukan Majelis Permusyawaratan Rakyat, Dewan Perwakilan Rakyat, Dewan Perwakilan Daerah, dan Dewan Perwakilan Rakyat Daerah, Undang-Undang Nomor 17 Tahun 2014 tentang Susunan dan Kedudukan Majelis Permusyawaratan Rakyat, Dewan Perwakilan Rakyat, Dewan Perwakilan Daerah, dan Dewan Perwakilan Rakyat Daerah dan yang terakhir Undang-Undang Nomor 2 Tahun 2018 tentang Susunan dan Kedudukan Majelis Permusyawaratan Rakyat, Dewan Perwakilan Rakyat, Dewan Perwakilan Daerah, dan Dewan Perwakilan Rakyat Daerah. Data yang digunakan adalah adalah data hukum sekunder yang berupa bahan hukum primer dan bahan hukum sekunder. Bahan hukum primer berpa peraturan perundang-undangan, sedangkan bahan hukum sekunder berupa bahan pustaka seperi literatur, dan artikel. Analisis data dalam artikel ini menggunakan analisis kualitatif dengan mendeskripsikan fakta-fakta yang ada, kemudian dilakukan analisis berdasarkan norma hukum yang berlaku maupun teori yang ada.

\section{Pembentukan Mahkamah Kehormatan Dewan}

Dewan perwakilan rakyat yang disingkat DPR merupakan lembaga perwakilan politik di dalam susunan ketata negaraan Indonesia. Anggota DPR direkrut dengan cara dipilih melalui pemilihan umum dari partai politik hal ini sesuai dengan konstitusi Indonesia yaitu bahwa anggota DPR dipilih melalui pemilihan umum ${ }^{5}$.

Pemilihan Umum (Pemilu) yang diselenggarakan secara serentak setiap lima tahun sudah selayaknya dijadikan momentum oleh anggota DPR untuk meraih kepercayaan rakyat dalam rangka memperjuangkan kepentingan mereka selama lima

\footnotetext{
${ }^{4}$ Bagir Manan, (2004), Teori dan Politik Konstitusi, FH UII Press, Yogyakarta, hal. 221

5 Reni Dwi Purnomowati, (2005), Implementasi Sistem Bicameral Dalam Parlemen Indonesia, PT Rajagrafindo Persada, Jakarta, hal. 201
} 
tahun ke depan. Hal tersebut dikarenakan keberhasilan pembangunan di tanah air pada hakikatnya merupakan hasil kerja bersama antara lembaga eksekutif dan legislatif. Dalam hal ini fungsi pengawasan serta persetujuan terkait anggaran yang dilakukan oleh lembaga legislatif (DPR) akan sangat menentukan terlaksananya program-program yang dicanangkan oleh lembaga eksekutif.

Ridho Budiman Utama dalam kolom opininya menyebutkan, bahwa menjalankan peran sebagai penyambung lidah rakyat, setiap wakil rakyat diharapkan mampu menyuarakan aspirasi masyarakat yang diwakilinya secara lugas. Wakil rakyat semestinya peka terhadap berbagai kebutuhan ataupun kesulitan yang dirasakan oleh masyarakat terutama yang menjadi konstituennya. Lebih jauh lagi, aspirasi yang disuarakannya itu mampu diwujudkan dalam berbagai program yang direalisasikan oleh lembaga eksekutif. Tidak hanya itu, wakil rakyat juga semestinya bersuara lantang manakala terdapat kebijakan yang dikeluarkan oleh lembaga eksekutif yang cenderung bertentangan dengan kepentingan rakyat. Sebagai pihak yang diberikan mandat oleh rakyat, tidak sepatutnya wakil rakyat hanya diam dan duduk manis menyaksikan masyarakat hidup dalam kesusahan ${ }^{6}$.

Beberapa fakta menunjukkan oknum anggota DPR melakukan tindakan yang tidak terpuji, tindakan yang justru bertentangan dengan kode etik DPR bahkan menjurus kepada tindakan pidana. Seperti yang kita ketahui diberbagai media baik media cetak maupun elektronik sudah sangat terang diberitakan tentang anggota dewan yang tidak ikut rapat bahkan tidak berkantor, bermain game pada saat rapat, tidur waktu sidang paripurna, sesama anggota DPR melakukan tidakan kekerasan/perkelahian, bahkan sudah menjurus ke tindakan pidana seperti korupsi.

Fenomena seperti diatas menjadi alasan utama untuk dibentuknya suatu badan yang menegakkan etika anggota dewan. Badan ini sangat penting segera dibentuk sebagai upaya reformasi etik, kode etik dan kode perilaku yang bersifat mengikat dan wajib ditaati oleh setiap anggota DPR, Ini merupakan respon atas tanggapan publik terhadap kinerja buruk sebagian anggota DPR Beberapa kasus pelanggaran kode etik inilah yang memunculkan desakan dibentuknya Mahkamah Kehormatan dewan (MKD).

Akhirnya dibentuklah MKD sebagaimana yang tertuang dalam Undang-Undang Nomor 22 tahun 2003 tentang susunan dan kedudukan Majelis Permusyawaratan

${ }^{6}$ https://www.pasundanekspres.co/opini/peran-anggota-dewan-dalam-memperjuangkan-kepentingan-rakyat/ 
Eksistensi Mahkamah Kehormatan Dewan Pasca Berlakunya Undang-Undang Nomor 2 Tahun 2018 Tentang Majelis Permusyawaratan Rakyat, Dewan Perwakilan Rakyat, Dewan Perwakilan Daerah, dan Dewan Perwakilan Rakyat Daerah

Rakyat, Dewan Perwakilan Rakyat, Dewan Perwakilan Daerah, Dan Dewan Perwakilan Rakyat Daerah. Badan Kehormatan DPR RI merupakan alat kelengkapan DPR RI yang baru, sebagaimana termaktub dalam Pasal 98 ayat (2) huruf g, Badan Kehormatan DPR RI dibentuk oleh DPR sebagai alat kelengkapan DPR yang bersifat tetap. Disebutkan bahwa Alat kelengkapan DPR terdiri atas:
a. Pimpinan;
b. Komisi;
c. Badan Musyawarah;
d. Badan Legislasi;
e. Badan Urusan Rumah Tangga;
f. Badan Kerjasama Antar-Parlemen;
g. Badan Kehormatan;
h. Panitia Anggaran; dan
i. Alat Kelengkapan lain yang diperlukan.

Undang Undang Nomor 22 Tahun 2003 tentang Susunan dan Kedudukan MPR, DPR,DPD, DPRD ini merupakan tonggak awal eksistensi Badan kehormatan dewan yang pada 2014 berubah penamaanya menjadi Mahkamah Kehormatan Dewan (MKD).

\section{Mahkamah Kehormatan Dewan Pasca Berlakunya Undang-Undang Nomor 17}

Tahun 2014 Dan Undang-Undang Nomor 2 Tahun 2018 Tentang Tentang Majelis Permusyawaratan Rakyat, Dewan Perwakilan Rakyat, Dewan Perwakilan Daerah, Dan Dewan Perwakilan Rakyat Daerah

Sejarah keberadaan lembaga penegak etik mulai diperkenalkan ketika berlakunya Undang-Undang Nomor 4 Tahun 1999 tentang Susunan dan Kedudukan MPR, DPR, dan DPRD. Namun di dalam undang-undang ini tidak disebutkan secara jelas terkait struktur kelembagaan, tugas, fungsi serta kewenangan dari MKD, UndangUndang ini pengaturan lebih lanjutnya didelegasikan ke dalam Peraturan DPR dalam bentuk Tata tertib DPR.

Kemudian lahirlah Undang-Undang No. 22 Tahun 2003 tentang susunan dan kedudukan MPR, DPR, DPD dan DPRD. Dalam ketentuan Undang-undang ini, MKD yang pada saat itu disebut badan kehormatan diatur dalam Pasal 98 yaitu Alat kelengkapan DPR terdiri atas:
a. Pimpinan; 
b. Komisi;

c. Badan musyawarah;

d. Badan legislasi;

e. Badan urusan rumah tangga;

f. Badan kerjasama antar-parlemen;

g. Badan kehormatan;

h. Panitia anggaran; dan

i. Alat kelengkapan lain yang diperlukan.

Dalam undang-undang tersebut belum diatur secara eksplisit tentang badan kehormatan dewan,

Badan kehormatan dewan sebagai lembaga penegakan etik ini dibentuk sebagai alat kelengkapan dewan yang selanjutnya dalam pasal 55 tata tertib DPR tahun 2004 barulah dinyatakan bahwa badan kehormatan dibentuk oleh DPR sebagai alat kelengkapan DPR yang bersifat tetap, yang kemudian juga disebutkan dalam tata tertib DPR nomor 08/DPR RI/I/2005-2006

Selanjutnya Undang-Undang Nomor 22 Tahun 2003 tentang Susunan dan Kedudukan MPR, DPR, DPD dan DPRD diganti dengan Undang-Undang Nomor 27 Tahun 2009 tentang MPR, DPR, DPD, dan DPRD. Kelembagaan pengawas dan penegakan etika kemudian diakui secara eksplisit sebagai alat kelengkapan dewan yang bersifat tetap yaitu Badan Kehormatan yang termuat dalam Pasal 123 UndangUndang Nomor 27 Tahun 2009 tentang MPR, DPR, DPD, dan DPRD, sebagai berikut Badan Kehormatan dibentuk oleh DPR dan merupakan alat kelengkapan DPR yang bersifat tetap.

Beratnya tugas dan tanggung jawab Badan Kehormatan memerlukan penguatan kewenangan yang dapat menunjang pelaksanaan fungsinya menegakan Citra DPR. Pengaturan terkait Badan Kehormatan DPR harus juga mampu memperkuat dari sisi kelembagaan sehingga kinerjanya dapat ditingkatkan. Aturan terkait Mahkamah kehormatan dewan DPR perlu ditata ulang. Hal ini penting untuk menghasilkan pola pengawasan yang efektif. Khusus untuk isu legal framework, BK harus diset sebagai lembaga pengawas anggota DPR yang memiliki wewenang proaktif dalam menjalankan tugasnya. Dengan demikian, kewajiban atau syarat adanya laporan pengaduan masyarakat dan perintah dari pimpinan DPR sudah semestinya dihapus. BK DPR juga 
perlu diposisikan independen dengan memasukkan unsur masyarakat dalam komposisi keanggotaan $\mathrm{BK}^{7}$.

Sangat menarik terkait dengan Undang-Undang Nomor 27 Tahun 2009 tentang MPR, DPR, DPD, dan DPRD ini karena pada aturan-aturan sebelumnya baik dalam bentuk Undang-Undang maupun dalam bentuk tata tertib DPR terkesan sangat pasif karena badan kehormatan baru akan merespon suatu tindakan yang diduga melanggar kode etik apabila ada pengaduan, jadi sifatnya menunggu pengaduan terhadap anggota kemudian bertindak.

Hal tersebut berbeda dengan berlakunya Undang-Undang Nomor 27 Tahun 2009 dan Peraturan DPR Nomor 2 tahun 2011 tentang tata beracara Badan Kehormatan DPR, dimana disebutkan dalam Tata Beracara badan kehormatan DPR bahwa mekipun tanpa ada pengaduan badan kehormatan dapat menindak bila ada pelanggaran kode etik. Hal itu disebutkan dalam Pasal 3 ayat (1) yaitu : Palanggaran yang tidak memerlukan pengaduan adalah pelanggaran yang dilakukan oleh anggota DPR RI berupa:

a. Ketidakhadiran dalam rapat DPR RI yang menjadi kewajibannya

b. Tertangkap tangan atas pelanggaran undang-undang

c. Dugaan pelanggaran kode etik dan tata tertib yang sudah tersiar di beberapa media cetak dan/atau elektronik dan;

d. Terbukti melakukan tindak pidana dengan ancaman lebih dari 5 (lima) tahun penjara dan telah mendapatkan putusan yang berkekuatan hukum tetap.

Hal tersebut merupakan respon atas kritikan yang selama ini ditujukan terhadap anggoda dewan khusunya badan kehormatan DPR untuk aktif menindak anggota yang diduga melanggar etika walaupun tanpa ada pengaduan.

Kemudian masa angkatan DPR tahun 2014-2019 kelembagaan etik DPR mengalami perubahan signifikan melalui Undang-Undang Nomor 17 Tahun 2014 tentang MPR, DPR, DPD, dan DPRD. ditandai dengan adanya perubahan nomenklatur dari Badan Kehormatan menjadi Mahkamah Kehormatan Dewan (MKD), yang tentunya perubahan ini akan membawa implikasi kepada struktur kelembagaan dari lembaga ini yang akan merujuk pada kewenangan serta keanggotaannya. Dalam Pasal 83 ayat (1) menyebutkan bahwa Alat kelengkapan DPR terdiri atas:

\footnotetext{
7 Marulak Pardede, (2011), Laporan Akhir Penelitian Hukum Tentang Efektivitas Putusan Badan Kehormatan DPR/DPRD, Badan Pembinaan Hukum Nasional Kementerian Hukum dan HAM-RI, Jakarta, hal. 48
} 
a. Pimpinan;

b. Badan Musyawarah;

c. komisi;

d. Badan Legislasi;

e. Badan Anggaran;

f. Badan Kerja Sama Antar-Parlemen;

g. Mahkamah Kehormatan Dewan;

h. Badan Urusan Rumah Tangga;

i. Panitia khusus; dan

j. Alat kelengkapan lain yang diperlukan dan dibentuk oleh rapat paripurna.

Dalam Undang-Undang Nomor 17 Tahun 2014 ini pula sangat jelas cara penentuan anggotanya terutama dalam tata tertib nomor 1 tahun 2014 yang tentunya langkah ini dilakukan untuk menyesuaikan pengisian keanggotaan sama dengan alat kelengkapan DPR yang lain. Dalam pasal 79 Tata tertib nomor 1 tahun 2014 disebutkan bahwa DPR menetapkan susunan dan keanggotaan MKD yang terdiri atas semua Fraksi dengan memperhatikan perimbangan dan pemerataan jumlah anggota setiap Fraksi pada permulaan masa keanggotaan DPR dan permulaan tahun sidang. Kemudian Anggota MKD berjumlah 17 (tujuh belas) orang dan ditetapkan dalam rapat paripurna DPR, selanjutnya Pimpinan DPR mengadakan konsultasi dengan pimpinan Fraksi untuk menentukan komposisi keanggotaan MKD dengan berdasarkan prinsip musyawarah untuk mufakat. Dan jika tidak tidak tercapai maka keputusan diambil berdasarkan suara terbanyak dalam rapat paripurna DPR ditetapkan dalam rapat paripurna DPR.

Terkait Tugas dan wewenang MKD hal tersebut dijelaskan dalam Pasal 119 ayat (2) Undang-Undang Nomor 17 Tahun 2014 tentang MPR, DPR, DPD, dan DPRD, bahwa MKD sebagaimana dimaksud pada ayat (1) bertujuan menjaga serta menegakkan kehormatan dan keluhuran martabat DPR sebagai lembaga perwakilan rakyat. Pasal tersebut kemudian dijelaskan secara terperinci dalam Pasal 2 Peraturan DPR Nomor 2 Tahun 2015 tentang Tata Beracara MKD DPR. Dalam peraturan tersebut menyebutkan bahwa dalam menjalankan tugasnya MKD memiliki kewenangan untuk memeriksa berbagai pihak yang berkaitan dengan kasus yang ditangani.

Setelah MKD melakukan semua tahapan proses pemeriksaan, MKD memutus berdasarkan hasil pemeriksaan tersebut. Putusan MKD tersebut bersifat final dan 
Eksistensi Mahkamah Kehormatan Dewan Pasca Berlakunya Undang-Undang Nomor 2 Tahun 2018 Tentang Majelis Permusyawaratan Rakyat, Dewan Perwakilan Rakyat, Dewan Perwakilan Daerah, dan Dewan Perwakilan Rakyat Daerah

mengikat sebagaimana disebutkan dalam pasal 147 undang-undang Nomor 17 tahun 2014 bahwa:

(1) Putusan Mahkamah Kehormatan Dewan bersifat final dan mengikat, kecuali mengenai putusan pemberhentian tetap anggota.

(2) Putusan Mahkamah Kehormatan Dewan mengenai pemberhentian tetap anggota sebagaimana dimaksud pada ayat (1) harus mendapatkan persetujuan rapat paripurna.

(3) Dalam hal putusan Mahkamah Kehormatan Dewan mengenai pemberhentian tetap anggota sebagaimana dimaksud pada ayat (2), putusan berlaku sejak tanggal mendapatkan persetujuan rapat paripurna.

Lebih lanjut disebutkan dalam Pasal 2 ayat (3) Peraturan DPR Nomor 2 Tahun 2015 tentang Tata Beracara Mahkamah Kehormatan Dewan Dewan Perwakilan Rakyat Republik Indonesia, bahwa Dalam menjalankan fungsi dan tugasnya, MKD berwenang untuk:

a. menerbitkan surat edaran mengenai anjuran untuk menaati Tata Tertib serta mencegah pelanggaran Kode Etik kepada seluruh Anggota;

b. memantau perilaku dan kehadiran Anggota dalam rapat DPR;

c. memberikan rekomendasi kepada pihak terkait untuk mencegah terjadinya pelanggaran Kode Etik dan menjaga martabat, kehormatan, citra, dan kredibilitas DPR;

d. melakukan tindak lanjut atas dugaan pelanggaran Kode Etik yang dilakukan oleh Anggota, baik berdasarkan Pengaduan maupun tanpa Pengaduan;

e. memanggil dan memeriksa setiap orang yang terkait tindakan dan/atau peristiwa yang patut diduga dilakukan oleh Anggota yang tidak melaksanakan salah satu kewajiban atau lebih dan/atau melanggar ketentuan larangan sebagaimana dimaksud dalam Peraturan DPR tentang Tata Tertib dalam Sidang MKD;

f. melakukan kerja sama dengan lembaga lain;

g. memanggil pihak terkait;

h. menghentikan proses pemeriksaan perkara dalam setiap persidangan dalam hal Pengadu mencabut aduannya atau diputuskan oleh Rapat MKD;

i. memutus perkara pelanggaran yang patut diduga dilakukan oleh Anggota yang tidak melaksanakan salah satu kewajiban atau lebih dan/atau melanggar ketentuan larangan sebagaimana dimaksud dalam undang-undang yang 
mengatur mengenai Majelis Permusyawaratan Rakyat, Dewan Perwakilan Rakyat, Dewan Perwakilan Daerah, dan Dewan Perwakilan Rakyat Daerah, Peraturan DPR yang mengatur tentang Tata

j. Tertib dan Kode Etik;11)menyusun rancangan anggaran untuk pelaksanaan tugasnya sesuai dengan kebutuhan yang selanjutnya disampaikan kepada badan urusan rumah tangga; dan

k. melakukan evaluasi dan penyempurnaan Peraturan DPR yang mengatur tentang Kode Etik. Dari segi pengambilan keputusan di Lembaga MKD, dapat dilihat bahwa lembaga ini diberikan kewenangan penuh layaknya seperti lembaga peradilan dan penegak etik yang sifatnya independen, karena putusan yang dibuat oleh Mahkamah sifatnya final dan mengikat, kecuali mengenai putusan pemberhentian anggota secara tetap harus mendapat persetujuan dari rapat paripurna. Sedangkan Anggota, pimpinan fraksi, dan/atau Pimpinan DPR tidak dibenarkan melakukan upaya intervensi terhadap putusan MKD, karena upaya intervensi terhadap putusan MKD merupakan pelanggaran Kode Etik.

Di dalam tata tertib DPR nomor 1 tahun 2014 yakni pasal 81 terkait dengan dimungkinkannya MKD membentuk panel untuk menangani kasus pelanggaran kode etik yang bersifat berat dan berdampak pada sanksi pemberhentian Anggota Panel terdiri atas 3 (tiga) orang anggota Mahkamah Kehormatan Dewan dan 4 (empat) orang dari unsur masyarakat. Anggota panel yang berasal dari MKD dipilih dari dan oleh anggota MKD berdasarkan prinsip musyawarah dan mufakat dan Apabila prinsip musyawarah dan mufakat tidak tercapai, 3 (tiga) anggota panel yang berasal dari MKD dipilih berdasarkan suara terbanyak dan kemudian ditetapkan dalam keputusan Mahkamah Kehormatan Dewan.

Kemudian Anggota panel yang berasal dari unsur masyarakat harus memiliki integritas yang mewakili akademisi, tokoh masyarakat, tokoh agama dan praktisi hukum. Pimpinan MKD menerima usulan bakal calon anggota panel yang berasal dari unsur masyarakat secara terbuka. Bakal calon anggota panel yang berasal dari unsur masyarakat diseleksi dan ditetapkan dalam rapat pleno MKD. dan Pembentukan panel paling lama 10 (sepuluh) Hari terhitung sejak MKD memutuskan adanya dugaan pelanggaran kode etik yang bersifat berat terhadap Anggota.

Panel ini tentunya bertujuan agar MKD lebih independen dalam mengambil keputusan terkait pelanggaran yang dilakukan anggota dewan, dan juga diharapkan 
dapat menambah kepercayaan masyarakat terhadap MKD karena adanya unsur dari luar, bukan hanya semata-mata unsur anggota dewan sehingga diyakini bahwa keputusannya terbebas dari intervensi kekuatan-kekuatan politik.

Kemudian dalam undang-undang Nomor 2 Tahun 2018 Tentang Perubahan Kedua Atas Undang-Undang Nomor 17 Tahun 2014 Tentang Majelis Permusyawaratan Rakyat, Dewan Perwakilan Rakyat, Dewan Perwakilan Daerah, Dan Dewan Perwakilan Rakyat Daerah tidak mengalami banyak perubahan signifikan, perubahan yang mencolok hanya terkait dengan penambahan unsur pimpinan MKD sebelumnya disebutkan Pimpinan Mahkamah Kehormatan Dewan terdiri atas 1 (satu) orang ketua dan paling banyak 2 (dua) orang wakil ketua yang dipilih dari dan oleh anggota Mahkamah Kehormatan Dewan dalam satu paket yang bersifat tetap berdasarkan usulan fraksi sesuai dengan prinsip musyawarah untuk mufakat. Sedangkan dalam undang-undang Nomor 2 Tahun 2018 mengalami perubahan yaitu (2) Pimpinan Mahkamah Kehormatan Dewan terdiri atas 1 (satu) orang ketua dan paling banyak 4 (empat) orang wakil ketua yang dipilih dari dan oleh anggota Mahkamah Kehormatan Dewan dalam satu paket yang bersifat tetap berdasarkan usulan fraksi sesuai dengan prinsip musyawarah untuk mufakat.

\section{Kesimpulan}

Berdasarkan uraian diatas eksistensi MKD secara normatif yakni berdasarkan Undang-Undang Nomor 17 Tahun 2014 yang kemudian diubah dengan UndangUndang Nomor 2 Tahun 2018 tentang MPR, DPR, DPD, dan DPRD kemudian juga secara rinci dijelaskan dalam tata tertib DPR dan tata beracara MKD dijelaskan secara eksplisit yang menyebutkan bahwa Majelis Kehormatan Dewan adalah suatu lembaga yang dibentuk oleh DPR dan merupakan alat kelengkapan DPR yang bersifat tetap serta memiliki tugas dan fungsi untuk menjaga dan menegakkan kehormatan serta keluhuran martabat DPR sebagai lembaga perwakilan rakyat yang senantiasa memperjuangkan aspirasi rakyat. Komposisi Mahkamah Kehormatan Dewan yang juga melibatkan unsur masyarakat dimaksudkan untuk menepis anggapan bahwa MKD tidak independen dalam menangani anggota dewan yang diduga melanggar kode etik.

\section{REFERENSI}

Bagir Manan, (2004), Teori dan Politik Konstitusi, Yogyakarta: FH UII Press. 
Eksistensi Mahkamah Kehormatan Dewan Pasca Berlakunya Undang-Undang Nomor 2 Tahun 2018 Tentang Majelis Permusyawaratan Rakyat, Dewan Perwakilan Rakyat, Dewan Perwakilan Daerah, dan Dewan Perwakilan Rakyat Daerah

Jimly Sssiddiqie, (2010), Perihal Undang-Undang, Jakarta: PT RajaGrafindo Persada Marulak Pardede, (2011), Laporan Akhir Penelitian Hukum Tentang Efektivitas Putusan Badan Kehormatan DPR/DPRD, Jakarta: Badan Pembinaan Hukum Nasional Kementerian Hukum dan HAM-RI.

Reni Dwi Purnomowati, (2005), Implementasi Sistem Bicameral Dalam Parlemen Indonesia, Jakarta: PT Rajagrafindo Persada.

Sri Karyati, (2015), Rekonstruksi Kelembagaan Penegakan Etika Parlemen, Jurnal Etika dan Pemilu, v1n1.

https://www.pasundanekspres.co/opini/peran-anggota-dewan-dalammemperjuangkan-kepentingan-rakyat/

https://mediaindonesia.com/read/detail/265856-hari-parlemen-indonesia-jadipengingat-amanat-kedaulatan-rakyat 